\title{
Diversity of Campylobacter Isolates from Three Activated Sludge Systems
}

\author{
AL Lauria-Filgueiras $^{+}$, E Hofer \\ Laboratório de Zoonoses Bacterianas, Instituto Oswaldo Cruz, Av. Brasil 4365, 21045-900 Rio de Janeiro, RJ, \\ Brasil
}

Thermophilic campylobacters were isolated from three sewage plants in Rio de Janeiro, RJ, Brazil and identified. Laboratory analysis of 390 sewage samples showed the presence of 169 thermophilic strains. The results demonstrated that human and animal pathogenic biotypes could be isolated from activated sludge during the initial processing steps. The aeration tank could be considered a barrier to Campylobacter survival. C. jejuni was the prevalent species isolated (40.8\%). The most common biotypes were C. jejuni biotype I (21.3\%), C. coli biotype I (16\%) and C. jejuni biotype II ( 14.8\%).

Key words: thermophilic campylobacters - sewage plants - incidence

During the past decade thermophilic campylobacters have been shown to be responsible for enteritis in human and animals (Smibert 1974, 1984, Ketley 1997). Campylobacter is a microaerophilic microorganism which can not proliferate in the environment but can survive fairly well in aqueous environments at low temperature (Stelzer et al. 1991). Studies in the United Kingdom, Germany, Italy, the Netherlands and Libya have shown that sewage is usually heavily contaminated with this pathogen; these papers have also detailed the importance of efflux from sewage plants as a major vehicle for the spread of pathogenic biotypes of $C$. jejuni and C. coli in the environment (Höller 1988, Betaieb \& Jones 1990, Jones et al. 1990a, Stelzer et al. 1991, Stampi et al. 1992, Höller \& Schomakers-Revaka 1994, Koenraad et al. 1994).

Based on the above facts and because there is no study in our country on this subject, we investigated the incidence and distribution of these bacteria during biological sewage treatment by the activated sludge process at three sewage plants in Rio de Janeiro, RJ, Brazil.

\section{MATERIALS AND METHODS}

Sample collection - Samples were collected in Rio de Janeiro, RJ, Brazil (Table I).

The Penha sewage treatment plant serves a permanent local population of approximately 700,000 inhabitants. In addition to domestic sewage, the plant receives considerable amounts of industrial

${ }^{+}$Corresponding author. Fax: + 55-21-280.0754/ 270. 6565. E-mail: analu@gene.dbbm.fiocruz.br Received 10 November 1997 Accepted 18 March 1998 and hospital wastes, with an estimated discharge volume of $1,400 \mathrm{l} / \mathrm{sec}$. Two treatments are applied at the plant, i.e., activated sludge and biological filters. The Governador Island plant serves about 90,000 persons and mainly treats domestic sewage using the activated sludge process. The Airport plant receives sewage from administration buildings, from the passenger terminal, from the support area and also from all aircrafts. The last type of sewage contains disinfectants at the levels required by law for the removal of polluting loads. The plant also uses the activated sludge process which has a mean efficiency of about $90 \%$. This influent receives material from airplanes and therefore from a fluctuating population consisting of passengers from all over the world.

Samples were collected at four different stages of biological treatment: influent, entry to the aeration tank, exit from the aeration tank, and effluent. An amount of $120 \mathrm{ml}$ of sewage was collected from each stage into sterile bottles, transferred to the laboratory within $1 \mathrm{hr}$ and immediately centrifuged at $3000 \mathrm{rpm}$ for $30 \mathrm{~min}$.

\section{TABLE I}

Distribution of sewage collection

\begin{tabular}{llc}
\hline Sewage plant & Period & No. of samples \\
\hline Penha & $\begin{array}{l}\text { 15 May 1990 } \\
\text { to 21 May 1991 }\end{array}$ & 120 \\
$\begin{array}{l}\text { Governador } \\
\text { Island }\end{array}$ & $\begin{array}{l}\text { 12 September 1990 } \\
\text { to 21 May 1991 }\end{array}$ & 140 \\
$\begin{array}{l}\text { International } \\
\begin{array}{l}\text { Airport of Rio } \\
\text { de Janeiro }\end{array}\end{array}$ & 26 February 1990 to & \\
\hline Total & & 130 \\
\hline
\end{tabular}


The Airport samples were collected at only two stages, i.e., influent and effluent. Moore's swab adaptations Hofer (1974) were kept submerged for $72 \mathrm{hr}$ in these residual waters. After this time, the swabs were placed in plastic bags, taken to the laboratory within less than $2 \mathrm{hr}$ of collection and analyzed immediately.

Isolation - Aliquots of $0.1 \mathrm{ml}$ of $0.5 \mathrm{ml} \mathrm{PBS}$ resuspension of the centrifuged material as well as $0.1 \mathrm{ml}$ of material squeezed from the swabs were inoculated onto selective plate medium (blood agar base, Columbia, Difco) containing $4 \mathrm{~g} \%$ of activated charcoal (Group Quimica), 5\% reducing solution FBP (George et al. 1978) and $0.5 \%$ of a mixture of the following antibiotics: trimethoprim lactate (Roche), cephalothin (Libra), vancomycin (Lilly), cyclohexamide (Upjohn), and colistin (Lafi) according to Filgueiras and Hofer (1989).

Plates were incubated at $43^{\circ} \mathrm{C}$ for $48 \mathrm{hr}$ in a candle jar prepared by a modification of the copper passivation technique using steel wool, antiacid tablets and an acidulated ( $\mathrm{pH}$ 2) copper solution (Filgueiras \& Hofer 1989).

Identification - Campylobacter growth was confirmed on the basis of colony morphology (gray, small, mucous or flat) and microscopic appearance. If the Gram-stained smears from suspected colonies showed Gram-negative bacteria morphologically similar to the genus Campylobacter, the material was submitted to the oxidase and catalase reactions. The colonies were then isolated in duplicate, with one isolate being maintained at low temperature $\left(-70^{\circ} \mathrm{C}\right)$ in Brucella broth with 0.16 $\mathrm{g} \%$ agar, and the other being used for biochemical tests (glucose fermentation, growth in 3.5\% sodium chloride, and in $1 \%$ glycine, reduction of nitrate to nitrite and $\mathrm{H}_{2} \mathrm{~S}$ production) and to demonstrate sensitivity to nalidixic acid (30 mg- Cecon) and resistance to cephalothin (30 mg-Cecon).

To complete the biotyping, according to scheme of Lior (1984), the material was submitted to the hippurate hydrolysis test and to deoxyribonuclease enzyme (DNase) detection.

\section{RESULTS AND DISCUSSION}

Sample analysis led to the isolation and identification of 169 thermophilic campylobacters at the three plants studied. Among them, 50\% were Campylobacter obtained at the Penha and Governador Island plants, probably due to human Campylobacter infection in the community and to birds, in particular at the Governador Island plant (Table II). The less frequent isolation obtained at the Airport sewage plant was possibly due to the fact that the sewage from aircraft was mixed with disinfectants. It should also be remembered that this sewage plant serves a fluctuating population whereas the other two receive influent from the permanent local population.

The samples obtained at different stages during biological sewage treatment (Tables III, IV, V) yielded a larger number of isolates during the first steps (influent and entry to the aeration tank), with the detection of the species and biotypes more frequently related to the human and animal enteric process $(C$. jejuni biotypes I and II and $C$. coli biotypes I and II), as reported in the literature (Arimi et al.1988, Filgueiras \& Hofer 1989, Stelzer et al. 1991, Stampi et al. 1992). A large amount of untyped strains was obtained after the aeration treatment, perhaps resulting from Campylobacter sensitivity to aeration, with a consequent modification in biochemical behavior.

There are no reports in the literature of the detection of $C$. jejuni biotype IV in residual water (Tables IV, V), nor about $C$. lari, a thermophilic species resistant to nalidixic acid. This detection in our study (Table IV) was possibly due to the presence of seagulls at the plant sampled from Governador Island.

The present results agree with data reported by Koenraad et al. (1994), who suggest the disinfection of sewage plant effluxes in order to obstruct the environmental cycles of Campylobacter, since the elimination is far from complete. Furthermore, Arimi et al. (1988) and Höller (1988) have reported that the reduction of campylobacters during the

TABLE II

Frequency of thermophilic campylobacters isolated from three sewage plants in Rio de Janeiro, RJ, Brazil

\begin{tabular}{lrrrrrrr}
\hline \multirow{2}{*}{ Plants } & \multicolumn{9}{c}{ Campylobacter } \\
\cline { 2 - 8 } & \multicolumn{2}{c}{ Positive } & \multicolumn{2}{c}{ Negative } & \multicolumn{2}{c}{ Total } \\
& No. & $\%$ & No. & $\%$ & No. & $\%$ \\
\hline Penha & 59 & 15.2 & 61 & 15.6 & 120 & 30.8 \\
Governador Island & 72 & 18.5 & 68 & 17.4 & 140 & 35.9 \\
International Airport of & 38 & 9.7 & 92 & 23.6 & 130 & 33.3 \\
Rio de Janeiro & & & & & & \\
\hline Total & 169 & 43.4 & 221 & 56.6 & 390 & 100.0 \\
\hline
\end{tabular}


TABLE III

Frequency of Campylobacter thermophilic species and biotypes according to the classification of Lior (1984), at different stages of biological treatment at the Penha sewage plant Rio de Janeiro, RJ, Brazil

\begin{tabular}{|c|c|c|c|c|c|c|}
\hline \multirow[t]{2}{*}{ Stages } & \multicolumn{2}{|c|}{ C. jejuni } & \multicolumn{2}{|c|}{ C. coli } & \multirow{2}{*}{$\begin{array}{c}\text { Campylobacter sp. } \\
\text { (untypable) }\end{array}$} & \multirow[t]{2}{*}{ Total } \\
\hline & I & II & I & II & & \\
\hline $\begin{array}{l}\text { Influent } \\
\mathrm{n}=30\end{array}$ & $\begin{array}{c}4 \\
(6.8)\end{array}$ & $\begin{array}{c}4 \\
(6.8)\end{array}$ & $\begin{array}{c}5 \\
(8.5)\end{array}$ & $\begin{array}{c}3 \\
(5.1)\end{array}$ & $\begin{array}{c}6 \\
(10.0)\end{array}$ & $\begin{array}{c}22 \\
(37.2)\end{array}$ \\
\hline $\begin{array}{l}\text { Entry to the aeration tank } \\
n=30\end{array}$ & $\begin{array}{c}10 \\
(16.9)\end{array}$ & $\begin{array}{c}3 \\
(5.1)\end{array}$ & $\begin{array}{c}2 \\
(3.4)\end{array}$ & 0 & $\begin{array}{c}3 \\
(5.1)\end{array}$ & $\begin{array}{c}18 \\
(30.5)\end{array}$ \\
\hline $\begin{array}{l}\text { Exit from the aeration tank } \\
\mathrm{n}=30\end{array}$ & $\begin{array}{c}2 \\
(3.4)\end{array}$ & $\begin{array}{c}3 \\
(5.1)\end{array}$ & $\begin{array}{c}3 \\
(5.1)\end{array}$ & 0 & $\begin{array}{c}4 \\
(6.8)\end{array}$ & $\begin{array}{c}12 \\
(20.4)\end{array}$ \\
\hline $\begin{array}{l}\text { Effluent } \\
\mathrm{n}=30\end{array}$ & 0 & 0 & $\begin{array}{c}1 \\
(1.7)\end{array}$ & $\begin{array}{c}1 \\
(1.7)\end{array}$ & $\begin{array}{c}5 \\
(8.5)\end{array}$ & $\begin{array}{c}7 \\
(11.9)\end{array}$ \\
\hline $\begin{array}{l}\text { Total } \\
n=120\end{array}$ & $\begin{array}{c}16 \\
(27.1)\end{array}$ & $\begin{array}{c}10 \\
(17.0)\end{array}$ & $\begin{array}{c}11 \\
(18.7)\end{array}$ & $\begin{array}{c}4 \\
(6.8)\end{array}$ & $\begin{array}{c}18 \\
(30.4)\end{array}$ & $\begin{array}{c}59 \\
(100.0)\end{array}$ \\
\hline
\end{tabular}

$\mathrm{n}$ : number of samples analized.

TABLE IV

Frequency of Campylobacter thermophilic species and biotypes. according to the classification of Lior (1984), at different stages of biological treatment at the Governador Island sewage plant, Rio de Janeiro, RJ, Brazil

\begin{tabular}{|c|c|c|c|c|c|c|c|c|}
\hline \multirow[t]{2}{*}{ Stages } & \multicolumn{3}{|c|}{ C. jejuni } & \multicolumn{2}{|c|}{ C. coli } & \multirow{2}{*}{$\begin{array}{l}\text { C. lari } \\
\text { I }\end{array}$} & \multirow{2}{*}{\multicolumn{2}{|c|}{$\begin{array}{l}\text { Campylobacter Total } \\
\text { sp. (untypable) }\end{array}$}} \\
\hline & I & II & IV & I & II & & & \\
\hline Influent & 5 & 5 & 1 & 2 & 4 & 1 & 5 & 23 \\
\hline $\mathrm{n}=35$ & $(6.9)$ & (6.9) & (1.4) & $(2.8)$ & $(5.6)$ & (1.4) & (6.9) & (31.9) \\
\hline $\begin{array}{l}\text { Entry to the aeration tank } \\
\mathrm{n}=35\end{array}$ & $\begin{array}{c}2 \\
(2.8)\end{array}$ & $\begin{array}{c}4 \\
(5.5)\end{array}$ & $\begin{array}{c}4 \\
(5.5)\end{array}$ & $\begin{array}{c}7 \\
(9.7)\end{array}$ & $\begin{array}{c}2 \\
(2.8)\end{array}$ & 0 & $\begin{array}{c}4 \\
(5.6)\end{array}$ & $\begin{array}{c}23 \\
(31.9)\end{array}$ \\
\hline $\begin{array}{l}\text { Exit from the aeration tank } \\
n=35\end{array}$ & $\begin{array}{c}2 \\
(2.8)\end{array}$ & 0 & 0 & $\begin{array}{c}2 \\
(2.8)\end{array}$ & $\begin{array}{c}2 \\
(2.8)\end{array}$ & 0 & $\begin{array}{c}9 \\
(12.5)\end{array}$ & $\begin{array}{c}15 \\
(20.9)\end{array}$ \\
\hline $\begin{array}{l}\text { Effluent } \\
\mathrm{n}=35\end{array}$ & $\begin{array}{c}1 \\
(1.4)\end{array}$ & $\begin{array}{c}1 \\
(1.4)\end{array}$ & $\begin{array}{c}1 \\
(1.4)\end{array}$ & $\begin{array}{c}1 \\
(1.4)\end{array}$ & $\begin{array}{c}1 \\
(1.4)\end{array}$ & 0 & $\begin{array}{c}6 \\
(8.3)\end{array}$ & $\begin{array}{c}11 \\
(15.3)\end{array}$ \\
\hline $\begin{array}{l}\text { Total } \\
\mathrm{n}=130\end{array}$ & $\begin{array}{c}10 \\
(13.9)\end{array}$ & $\begin{array}{c}10 \\
(13.9)\end{array}$ & $\begin{array}{c}6 \\
(8.3)\end{array}$ & $\begin{array}{c}12 \\
(16.7)\end{array}$ & $\begin{array}{c}9 \\
(12.5)\end{array}$ & $\begin{array}{c}1 \\
(1.4)\end{array}$ & $\begin{array}{c}24 \\
(33.3)\end{array}$ & $\begin{array}{c}72 \\
(100.0)\end{array}$ \\
\hline
\end{tabular}

$\mathrm{n}$ : number of samples analized.

TABLE V

Frequency of Campylobacter thermophilic species and biotypes according to the classification of Lior (1984), at different stages of biological treatment at the International Airport of Rio de Janeiro sewage plant, Rio de Janeiro, RJ, Brazil

\begin{tabular}{lccccccc}
\hline Stages & I & $\begin{array}{c}\text { C. jejuni } \\
\text { II }\end{array}$ & IV & I & II & $\begin{array}{c}\text { Campylobacter } \\
\text { sp. (untypable) }\end{array}$ & Total \\
\hline Influent & 7 & 3 & 2 & 2 & 1 & 8 & 23 \\
$\mathrm{n}=65$ & $(18.4)$ & $(7.9)$ & $(5.3)$ & $(5.3)$ & $(2.6)$ & $(21.0)$ & $(60.5)$ \\
Effluent & 3 & 2 & 0 & 2 & 0 & 8 & 15 \\
$\mathrm{n}=65$ & $(7.9)$ & $(5.3)$ & & $(5.3)$ & & $(21.0)$ & $(39.5)$ \\
\hline Total & 10 & 5 & 2 & 4 & 1 & 16 & 38 \\
$\mathrm{n}=130$ & $(26.3)$ & $(13.2)$ & $(5.3)$ & $(10.6)$ & $(2.6)$ & $(42.0)$ & $(100.0)$ \\
\hline
\end{tabular}

$\mathrm{n}$ : number of samples analized.

final step of treatment reached levels of 99.6 and $100 \%$, respectively. In this respect, it should be pointed out that the Governador Island sewage plant was working at reduced capacity throughout 1990 due to repairs (Table IV), what may explain the lower rate of Campylobacter elimination obtained at this plant compared to the Penha plant (Table V).

Another interesting aspect was the detection of a high percentage of untyped strains at all sewage 
treatment plants (Tables III, IV, V). A possible explanation for this fact is the hypothesis of environmental effects or even selective pressure on the microorganisms (Arimi et al. 1988, Höller 1988, Jacob et al. 1990, Jones et al. 1990b). In general, survival of campylobacters in sewage may be limited by the high organic load (Höller \& Schomakers-Revaka 1994).

The loss of viability during laboratory identification is considered to be due to the sudden change in environmental conditions, and exposure to high or low temperatures, oxygen or toxic substances that may quickly result in transition to a non-cultivable stage, with a sudden change to coccoid forms (Rollins \& Colwell 1986). In addition, in agreement with data reported by most investigators, we also observed the presence of a large number of viable but not cultivable Campylobacter cells (Rollins \& Colwell 1986, Carter et al. 1987, Höller 1988, Humphrey 1989, Pokorny 1990, Jacob \& Stelzer 1992, Höller \& Schomakers-Revaka 1994).

Finally, analysis of species and biotype distribution at the sewage plants showed the predominance of $C$. jejuni biotypes I and II, in agreement with data reported by others (Taylor et al. 1983, Carter et al. 1987, Arimi et al. 1988, Jones et al. 1990c, Stampi et al. 1992). This is explained by the fact that $C$. jejuni is the species most frequently detected in man and most frequently responsible for enteritis caused by campylobacters, probably reflecting its best adaptation and diffusion among human beings.

\section{REFERENCES}

Arimi SM, Fricker CR, Park RWA 1988. Occurrence of thermophilic campylobacters in sewage and their removal by treatment process. Epidem Inf 101: 279286.

Betaieb M, Jones K 1990. Thermophilic campylobacters in two treatment plants in Libya. Lett Appl Microbiol 11: 93-95.

Carter AM, Pacha RE, Clark GW, Williams EA 1987. Seasonal occurrence of Campylobacter spp. in surface waters and their correlation with standard indicator bacteria. Appl Environ Microbiol 53: 523-526.

Filgueiras ALL, Hofer E 1989. Ocorrência de Campylobacter termofílico em diferentes pontos de uma estação de tratamento de esgotos na cidade do Rio de Janeiro, RJ. Rev Microbiol (São Paulo) 20: 303-308.

George HA, Hoffman PS, Smibert RM, Krieg NR 1978. Improved media for growth and aerotolerance of $C$. fetus. J Clin Microbiol 8: 36-41.

Hofer E 1974. Métodos utilizados para o isolamento e identificação de Vibrio cholerae. Informe Patologia Clínica, Rio de Janeiro, 1: 5-18.

Höller C 1988. Long-term study of occurrence, distribution and reduction of Campylobacter sp. in the sewage system and wastewater treatment plant of a big town. Wat Sci Tech 20: 529-531.
Höller C, Schomakers-Revaka U 1994. A note: comparison of different homogenization procedures for detecting Campylobacter spp. in sewage sludge. $J$ Appl Bacteriol 77: 591-596.

Humphrey TJ 1989. An appraisal of the efficacy of preenrichment for the isolation of Campylobacter jejuni from water and food. J Appl Bacteriol 66: 119-126.

Jacob J, Stelzer W 1992. Comparison of two media for the isolation of thermophilic Campylobacter from waste waters of different quality. Zentralbl Mikrobiol 147: 41-44.

Jacob J, Bindemann U, Stelzer W 1990. Identification of Campylobacter jejuni and Campylobacter coli from wastewater by SDS-disc-page of whole cell protein. Zbl Hyg 190: 357-364.

Jones K, Betaieb M, Telford DR 1990a. Thermophilic campylobacters in surface waters around Lancaster, UK: negative correlation with Campy-lobacter infections in the community. J Appl Bacteriol 69: 758-764.

Jones K, Betaieb M, Telford, DR 1990b. Correlation between environmental monitoring of thermophilic campylobacters in sewage effluent and the incidence of Campylobacter infection in the community. $J$ Appl Bacteriol 69: 235-240.

Jones K, Betaieb M, Telford DR 1990c. Seasonal variation of thermophilic campylobacters in sewage sludge. J Appl Bacteriol 69: 185-189.

Ketley JM 1997. Pathogenesis of enteric infection by Campylobacter. Microbiology 143: 5-21.

Koenraad PMFJ, Hazeleger WC, van der Laan T, Beumer RR, Rombouts FM 1994. Survey of Campylobacter spp. in sewage plants in The Netherlands. Food Microbiol 11: 65-73.

Lior H 1984. New extended biotyping scheme for Campylobacter jejuni, Campylobacter coli and "Campylobacter laridis". J Clin Microbiol 20:636640.

Pokorny J 1990. To the problem of $C$. jejuni detectability in water. JHyg Epidemiol Microbiol Immun 34: 57-61.

Rollins DM, Colwell RR 1986. Viable but nonculturable stage of Campylobacter jejuni and its role in survival in the natural aquatic environment. Appl Environ Microbiol 52: 531-538.

Smibert RM 1974. Campylobacter, p. 207-211. In RE Buchanan \& NE Gibbons (eds), Bergey's Manual of Determinative Bacteriology, 8th ed., The Williams \& Wilkins Co., Baltimore.

Smibert RM 1984. Campylobacter, p. 111-118. In NR Krieg \& JG Holt (eds), Bergey's Manual of Systematic Bacteriology, 8th ed., vol. 1, The Williams \& Wilkins Co., Baltimore.

Stampi S, Varoli O, de Luca G, Zanetti F 1992. Occurrence, removal and seasonal variation of "thermophilic" campylobacters in a sewage treatment plant in Italy. Zbl Hyg 191: 199-210.

Stelzer W, Jacob J, Schulze E 1991. Environmental aspects of Campylobacter infections. Zentralbl Mikrobiol 146: 3-15.

Taylor DN, McDermott KT, Little JR, Wells JG, Blaser MJ 1983. Campylobacter enteritis from untreated water in the Rocky mountains. Ann Int Med 99: $38-40$. 